\title{
Karya Terjemahan Hadis Abad ke-19: Penyelenggaraan Teks Karya Nadir Hidāyat al-Mukhtār oleh Tuan Hasan Besut
}

\author{
Amer Hudhaifah Hamzah \\ Universiti Malaya, amerukun@gmail.com \\ Ahmad Arifin Sapar \\ Universiti Malaya, arifin@um.edu.my
}

\begin{abstract}
Abstrak
Manuskrip merupakan suatu bentuk tinggalan sejarah yang sangat bermakna bagi sesebuah bangsa. Manuskrip dan karya-karya nadir berpotensi menjadi produk pelancongan jika ia dimanfaatkan. Kajian ini bertujuan membuktikan kenadiran dan keunikan karya Hidāyat alMukhtār oleh Tuan Hasan Besut pada abad ke-19 di samping menjalankan transliterasi teks terhadap karya tersebut. Pendekatan yang digunakan dalam membuktikan kenadiran karya Hidāyat al-Mukhtār adalah semakan automatik (auto finding) terhadap katalog-katalog digital Manuskrip Islam seluruh dunia dengan bantuan perisian al-Bāhith fī alMakhṭuṭāt al-Islāmiyyah yang disediakan oleh laman web Jāmi‘ alMakhțūtāt al-Islāmiyyah di alamat url www.wqf.me. Manakala kajian Transliterasi pula dilakukan dengan bantuan Kamus Dewan dan alMu jam al-Wasịt bagi menyemak makna-makna perkataan bahasa Arab. Dapatan menunjukkan meskipun edisi cetakan pertama Hidāyat alMukhtār (tahun 1833) mengandungi masalah bahasa dan kesalahan percetakan, namun ia penting kerana berjaya menyelamatkan sebuah karya Hadis al-Hāfiz al-Mundhirī, ulama hadis Mesir abad ke-7 Hijri bersamaan 13 Masihi, yang dianggap telah hilang. Selain itu, berdasarkan riwayat hidup Tuan Hasan Besut dan tinjauan terhadap teks karya Hid̄̄yat al-Mukhtār, dapat disimpulkan bahawa beliau merupakan seorang pendidik yang disanjungi di Besut pada abad ke-19, ketiga-tiga karya asli dan terjemahan Tuan Hasan Besut dijangkakan mempunyai nilai ilmu pendidikan dan psikologi yang sangat bermakna untuk dibuat kajian lanjutan.
\end{abstract}

Kata kunci: Hidāyat al-Mukhtār, produk pelancongan, karya nadir, karya Hadis Alam Melayu, Wan Hasan al-Fatani, ilmu pendidikan dan psikologi

\section{The 19th Century Translation Work of Hadith: Textual Criticism of the Unique Work Hidāyat al-Mukhtār by Tuan Hasan Besut}

\section{Abstract}

Manuscript is a kind of meaningfully historical legacy for a particular ethnic race. Manuscript and unique works have potential to be tourism products if both are used. This research aims to prove the uniqueness of 
Hidāyat al-Mukhtār's masterpiece by Tuan Hasan Besut in the 19th century as well as transliterating the text of the work. The approach used in order to prove the uniqueness is auto finding towards digital catalogues of Islamic Manuscript entire world with the support from the al-Bāhith fì al-Makhțuțāt al-Islāmiyyah software at the link address www.wqf.me. Meanwhile the transliteration research was carried out with the support from Kamus Dewan and al-Mu'jam al-Wasīt in order to check the meanings of Arabic words. The findings depict even though the 1st Edition of Hidāyat al-Mukhtār (1833) consist of language problem and printing error, however it is important because successfully saved a hadith works of al-Häfiz al-Mundhirī, an Egyptian hadith scholar in the 7th century Hijri / 13M, that was assumed lost. Besides that, based on biography of Tuan Hasan Besut and the survey towards Hidāyat alMukhtār works text, it can be concluded that he was a respected teacher in Besut in the 19th century, all the three original and translation works of Tuan Hasan Besut are expected to have an education and psychology value that very useful to be carried for further studies.

Keywords: Hidāyat al-Mukhtār, tourism products, rare works, Hadis works of Malay World, Wan Hasan al-Fatani, knowledge of education and psychology

\section{Pendahuluan}

Menulis atau merekodkan merupakan suatu wasilah untuk mengekalkan sesuatu ilmu yang umum diketahui pada hari ini. Rekod dan hasil catatan juga dipercayai sebagai bukti konkrit yang menunjukkan sesuatu perkara atau peristiwa itu benar-benar terjadi dan diketahui, setidak-tidaknya bagi orang yang mencatat dan merekodkannya itu. Perkara ini secara umum diakui tidak kira dari bangsa atau mana sekalipun seseorang itu. Namun begitu, kemahiran menulis atau merekodkan ilmu bukanlah suatu yang biasa bagi orang Melayu pada masa dahulu, khususnya sebelum kedatangan Islam pada abad ke-13 Masihi. Alatan yang digunakan dalam penulisan juga sukar diperoleh pada waktu itu. ${ }^{1}$ Justeru setelah agama Islam diperkenalkan, seseorang yang ingin memiliki karya-karya agama atau naskhah al-Qur'an selalunya perlu

1 Amer Hudhaifah Hamzah, "Qaḍāyā al-Makhṭūtāt al-Malāyūwiyyah: Ațrūḥah Fikriyyah wa Iqtirāḥ," (Prosiding Seminar Antarabangsa Penyelidikan Alam Melayu, 2017), 322. 
mengupah orang lain yang mahir menulis agar menyalinnya untuk dirinya. $^{2}$

Sudah menjadi fitrah bahawa sesuatu yang sukar ataupun sedikit akan dianggap bernilai. Umum mengetahui kaedah: "semakin sikit atau sukar sesuatu itu, maka akan lebih tinggi nilainya". Apatah lagi jika ia mengandungi nilai sejarah dan warisan sesuatu kaum. Hal ini berlaku terhadap mana-mana warisan manuskrip di dunia ini, khususnya di Alam Melayu. Malah sesebuah hasil manuskrip mempunyai nilai seni yang tersendiri berdasarkan usia, corak dan kandungannya. Keadaan ini menyebabkan ia tidak boleh disamakan dengan hasil-hasil seni yang lain dan kesnya unik dan tidak boleh digeneralisasikan. ${ }^{3}$ Sehubungan itu, kita mendapati harga manuskrip asli pada hari ini boleh mencecah puluhan ribu ringgit (kira-kira 5.000-7.000 GBP). Hal ini boleh dilihat secara lelong di Sotheby atau Christie di London. Dalam kes Manuskrip Melayu pula, telah dilaporkan oleh akhbar Berita Harian (11 Julai 2006) bahawa kerajaan Malaysia melalui Kementerian Kebudayaan, Kesenian dan Warisan pernah bercadang membawa pulang sebahagian khazanah Manuskrip Melayu yang tersimpan di beberapa universiti di Britain, namun kerana harganya yang terlalu tinggi menyebabkan cadangan terpaksa dibatalkan. ${ }^{4}$

Seperti yang telah dijelaskan, nilai sesebuah manuskrip atau karya tradisional tidak hanya terletak kepada aspek-aspek tertentu seperti kandungannya yang nadir atau fizikal yang masih utuh walaupun lama, tetapi ia bergantung kepada keseluruhan aspek dan pemboleh ubah tersebut secara bersepadu. Justeru itu didapati bahawa seorang pengkaji manuskrip tidak akan berasa puas hanya dengan meneliti isi kandungannya yang telah didigitalkan sematamata. Bahkan beliau akan mencuba sedaya mungkin untuk menilik dan memegang sendiri fizikal manuskrip yang sedang dikaji.

2 Wan Ali Wan Mamat, "Persiapan untuk Kerja Menulis Manuskrip" dlm. Warisan Manuskrip Melayu (Kuala Lumpur: Perpustakaan Negara Malaysia, 2002), 24.

3 Dzul Haimi Md. Zain \& Md. Yusoff Othman, Ragam Hias al-Qur'an di Alam Melayu (Kuala Lumpur: Utusan Publications \& Distributors Sdn. Bhd., 2007), 14.

4 Hassan Omar, "Caj Tinggi Punca Manuskrip Melayu Tersimpan di Britain”, laman sesawang Berita Harian, dicapai pada 14 Oktober 2017, https://goo.gl/smq7nx. 
Begitu juga dalam melakukan transliterasi atau menjalankan kajian Tahqiq terhadap sesebuah manuskrip/karya tradisional, pastinya akan disediakan suatu slot khas untuk digambarkan secara deskriptif berkenaan sifat fizikal dan kondisi manuskrip atau karya tradisional tersebut. Elemen-elemen ini penting bagi menggambarkan kualiti naskhah, keaslian manuskrip/karya tradisional yang dikaji di samping mengekalkan nilai estetikanya. Gambar halaman doxology (pertama) dan colophon (terakhir) juga selalunya perlu dipaparkan oleh pengkaji untuk tujuan yang sama. ${ }^{5}$

Sehubungan di atas, seorang pengkaji manuskrip akan sentiasa berjalan ke sana dan ke sini bagi mencari dan meneliti manuskrip. Segala kerenah birokrasi sedia ditanggung dan mungkin juga sejumlah kos yang besar berani dibelanjakan hanya semata-mata untuk mencapai kepuasan dan keabsahan yang tinggi semasa menyediakan laporan kajian. Sering kali juga, kajian yang dijalankan merupakan geran penyelidikan atau ditaja oleh pihakpihak tertentu yang berkepentingan. Keadaan ini pastinya akan memberikan pulangan yang positif dan signifikan kepada pemilik sumber. Lebih dari itu jika sumber merupakan koleksi nadir, maka ia juga mampu menjadi daya tarikan kepada para pelancong asing dan pengkaji luar negara. Sudah tentu hal ini akan memangkin industri pelancongan dalam negara dan antarabangsa. Justeru, Sinar Harian (15 Julai 2013) melaporkan kenyataan Menteri Pelancongan dan Kebudayaan, Mohamed Nazri Abdul Aziz yang berkata Perpustakaan Negara Malaysia berpotensi menjadi tarikan pelancong dengan koleksi inteleknya yang kedua terbesar di Asia Tenggara selepas Indonesia. ${ }^{6}$

Berdasarkan penyelidikan yang dilakukan oleh pengkaji pada 2017, termasuk karya nadir yang sangat bernilai dalam khazanah

\footnotetext{
'Abd al-Salām Hārūn, Taḥqīq al-Nuṣūṣ wa Nashruhā (cet. ke 7, Kaherah: Maktabat al-Khanji, 1998), 84; Șalāḥ al-Dīn al-Munajjid, Qawā 'id Tahqīq alMakhțūtāt (cet. ke 7, Kaherah: Dār al-Kitab al-Jadīd, 1987), 29-30; Gotthelf Bergstraesser, Ușūl Naqd al-Nușūṣ wa Nashr al-Kutub, ed. Muhammad Hamdi al-Bakri (Riyadh: Dār al-Mirrikh, 1982), 125; Siti Hawa Haji Salleh, "Ruang Lingkup Pengajian Filologi Melayu", Jurnal Filologi Melayu 3 (1994), 4; Amer Hudhaifah Hamzah, Kitab al-Risalah al-Fataniyyah fi alNahw: Tahqiq dan Analisis Kandungan" (Disertasi, Fakulti Pengajian Islam, Universiti Kebangsaan Malaysia, 2016), 32-33.

6 Anon, "PNM Boleh Jadi Tarikan Pelancong", laman sesawang Sinar Online, https://goo.gl/LA9XCk, dicapai pada 14 Oktober 2017.
} 
Alam Melayu adalah sebuah karya terjemahan Hadis 40 berjudul Hidāyat al-Muktār yang tulis oleh Tuan Hasan Besut sebelum pertengahan abad ke-19. Dakwaan ini akan dibuktikan berdasarkan fakta dan data yang akan dinyatakan nanti. Walaupun pernah diperkenalkan oleh sebilangan pengkaji seperti Wan Mohd Shaghir dan lain-lain sebelum ini, namun artikel ini bertujuan memperkenalkannya secara lebih terperinci karya Hidāyat alMukhtār, selain turut memaparkan sebahagian dari hasil penyelenggaraan dan penelitian teks karya.

\section{Skop dan Metodologi Kajian}

Kajian ini merupakan suatu bentuk kajian deskriptif yang menggunakan pendekatan analisis Kualitatif. Objektifnya adalah untuk membuktikan nilai kenadiran dan keunikan pada karya Tuan Hasan Besut yang diberi judul Hidāyat al-Mukhtār atau juga dikenali sebagai Terjemahan Hadis 40 al-Shaykh 'Abd al-'Azim al-Mundhiri ini. Di samping itu, penelitian tekstual dari perspektif amali transliterasi yang dijalankan pula adalah bermaksud memberi gambaran langsung sekurang-kurangnya $1 / 8$ dari keseluruhan teks Hidāyat al-Mukhtār. Ia bertujuan memberi kebebasan kepada pembaca untuk membaca dan menilai sendiri kandungan karya yang dianggap nadir ini.

Bagi membuktikan kenadiran karya Hidāyat al-Mukhtār, pengkaji menggunakan metode semakan automatik (auto finding) terhadap katalog-katalog digital Manuskrip Islam seluruh dunia. Kaedah ini dilaksanakan dengan bantuan perisian al-Bāhith fi alMakhțūtāt al-Islāmiyyah) yang disediakan oleh laman web Jāmi al-Makhțūtāt al-Islāmiyyah di alamat www.wqf.me. Manakala berkenaan penelitian tekstual, pengkaji bertanggungjawab melakukan alihan aksara Jawi kepada aksara Rumi dengan sistem ejaan terkini berdasarkan Kamus Dewan dengan rujukan khas terhadap al-Mu'jam al-Wasīt bagi maksud-maksud perkataan bahasa Arab. Setiap komentar pengkaji diletakkan di bahagian nota kaki untuk memudahkan rujukan. Ini bertujuan memudahkan para pembaca zaman ini memahami teks karya Hidāyat alMukhtār yang besar manfaatnya kepada sejarah pendidikan Islam di dunia Melayu. Dalam masa yang sama, para pembaca juga dapat menilai sendiri keunikan karya ini berdasarkan isi kandungannya. 


\section{Riwayat Hidup Pengarang}

Wan Hasan al-Fatani atau lebih umum dikenali sebagai Tuan Hasan Besut merupakan anak kedua kepada Wan Ishak al-Fatani. Keluarga ulama ini yang mencangkupi Wan Ishaq (bapa), Wan Ali (abang) dan Wan Hasan mempunyai talian kekeluargaan dengan keluarga Abdul Mubin bin Jailani yang terkenal sebagai pengasas Pondok Pauh Bok di Patani. Di pondok bersejarah inilah terdidiknya sebilangan tokoh-tokoh ulama dan pejuang Alam Melayu yang terkenal seperti Daud al-Fatani, Abdus Samad alFalimbani dan Tok Pulai Chondong.

Tidak diketahui tanggal kelahiran Wan Hasan, namun Wan Ali bin Wan Ishaq dikatakan hampir sebaya dengan Daud bin Abdullah al-Fatani yang lahir pada $1740 \mathrm{M}$ dan antara mereka wujud hubungan persahabatan dan keilmuan yang erat. Wan Ali yang merupakan penyebar tarekat al-Sammaniyyah semasa hidupnya merupakan sumber rujukan Daud al-Fatani dalam halhal berkenaan Tasawwuf, khususnya dalam ajaran tarekat tersebut. Walaupun begitu dari aspek ilmu-ilmu yang lain, Wan Ali dilihat lebih banyak belajar dari Daud bin Abdullah al-Fatani kerana usianya yang lebih tua dan keluasan bidang ilmu yang diceburinya. ${ }^{7}$ Hasan bin Wan Ishak pula disifatkan sebagai seangkatan dengan Abdul Kadir Bukit Bayas yang merupakan ulama separuh akhir abad ke $18 \mathrm{M}$ dan awal abad ke $19 \mathrm{M} .{ }^{8}$

Sewaktu kecil lagi, kedua-dua bersaudara Wan Ali dan Wan Hasan telah memulakan pengajian mereka di Pondok Pauh Bok. Namun tidak dapat dipastikan apakah mereka sempat menimba ilmu dari Abdul Rahman bin Abdul Mubin yang terkenal antaranya sebagai guru kepada Daud al-Fatani, Tok Pulai Chondong dan Abdus Samad al-Falimbani. Apa yang pasti, mereka telah menimba ilmu dari bapa mereka sendiri, Wan Ishak al-Fatani yang merupakan antara tenaga pengajar di Pondok Pauh Bok. Kira-kira pada awal abad ke 19, Wan Ali dan Wan Hasan telah pergi ke Mekah bagi melengkapkan syarat keilmuan mereka. Di kota Mekah, mereka berguru dengan ulama-ulama Arab di

7 Wan Mohd Shaghir, Penyebaran Islam \& Silsilah Ulama Sejagat Dunia Melayu (Kuala Lumpur: Persatuan Pengkaji Khazanah Klasik Nusantara \& Khazanah Fathaniyah, 2000), 13:37-38.

8 Ahmad Fathy al-Fatani, Ulama Besar dari Patani (Bangi: Penerbit Universiti Kebangsaan Malaysia, 2002), 251. 
samping turut menimba ilmu dari sebilangan ulama Melayu yang bergiat di Tanah Haram seperti Muhammad Salih bin Abdul Rahman Pauh Bok dan Daud bin Abdullah al-Fatani sendiri. Sebilangan manuskrip peninggalan Syeikh Wan Ali al-Fatani, antaranya manuskrip Kayfiyyah Khatam al-Qur'ān, telah membuktikan hubungan keilmuan ini di Mekah.

Bermula tahun 1820-an di kota Mekah, Wan Hasan telah menghasilkan karya selain bergiat dalam bidang penterjemahan manuskrip Arab. Karya yang menjadi karang pertama Wan Hasan al-Fatani adalah sebuah manuskrip mengenai ilmu Firasat, berjudul Kitāb al-Fa'al, yang diselesaikan pada bulan Muharam $1240 \mathrm{H}$ bersamaan September 1824M. Karya ini ditulis dalam sebuah manuskrip bersama-sama naskhah salinan karya sahabat beliau, iaitu Abbas Kota Karang, Aceh, yang berjudul Sirāj alZulām fì Ma'rifat al-Sa'd wa al-Nahs fì al-Shahr wa al-Ayyām. Manuskrip ini telah disimpan oleh Khazanah Fathaniyah, Kuala Lumpur sebelum ia diserah untuk disimpan di Pusat Manuskrip Melayu, Perpustakaan Negara Malaysia dengan nombor pendaftaran MSS 1637.

Menurut Wan Mohd Shaghir, manuskrip ini pernah dicetak oleh Ismail bin Abdul Muttalib, Aceh dengan judul Tãj al-Mulūk. Ujar beliau juga, antara edisi cetakan dan edisi manuskrip terdapat perbezaan fakta. ${ }^{9}$ Manakala terjemahan yang lakukan adalah terjemahan karya Arba 'ūn Hadīthan fì Fadl Talab al-'Ilm oleh alMundhirī (1833) dan terjemahan risalah Ayyuhā al-Walad oleh alGhazālī (1850M). ${ }^{10}$ Cetakan pertama karya terjemahan Ayyuhā alWalad ini telah diusahakan oleh Abdullah Idris Tikat, Kelantan, di al-Matba'ah al-Miriyyah al-Kayniyyah, Mekah pada 17 Rabi'ul Awal 1311 H / 27 September 1893 M. Dalam masa yang sama, Wan Hasan turut mengajar di Mekah dan keilmuannya tidak hanya diiktiraf oleh ulama-ulama dari tanah airnya, malah turut diiktiraf dalam kalangan ulama Indonesia. Muhammad Zainuddin Aceh adalah sahabat seperguruannya di Mekah dan Nawawi Banten pula merupakan antara pelajarnya yang berasal dari Indonesia.

\footnotetext{
9 Wan Mohd Shaghir, Penyebaran Islam \& Silsilah Ulama Sejagat Dunia Melayu, 42-43.

10 Mohd Fauzi Hamat \& Mohd Hasrul Shuhari, "Pengaruh Pemikiran Akidah alGhazali dalam Kitab Jawi: Tinjauan Terhadap Kitab al-Durr al-Nafis dan Siyar al-Salikin", Jurnal Usuluddin 36 (2012), 32.
} 
Rajah 1: Halaman pertama MSS 1637 yang merupakan permulaan karya Sirāj al-Zulām $f \bar{\imath}$ Ma 'rifat al-Sa'd wa al-Nahs fĩ al-Shahr wa al-Ayyām

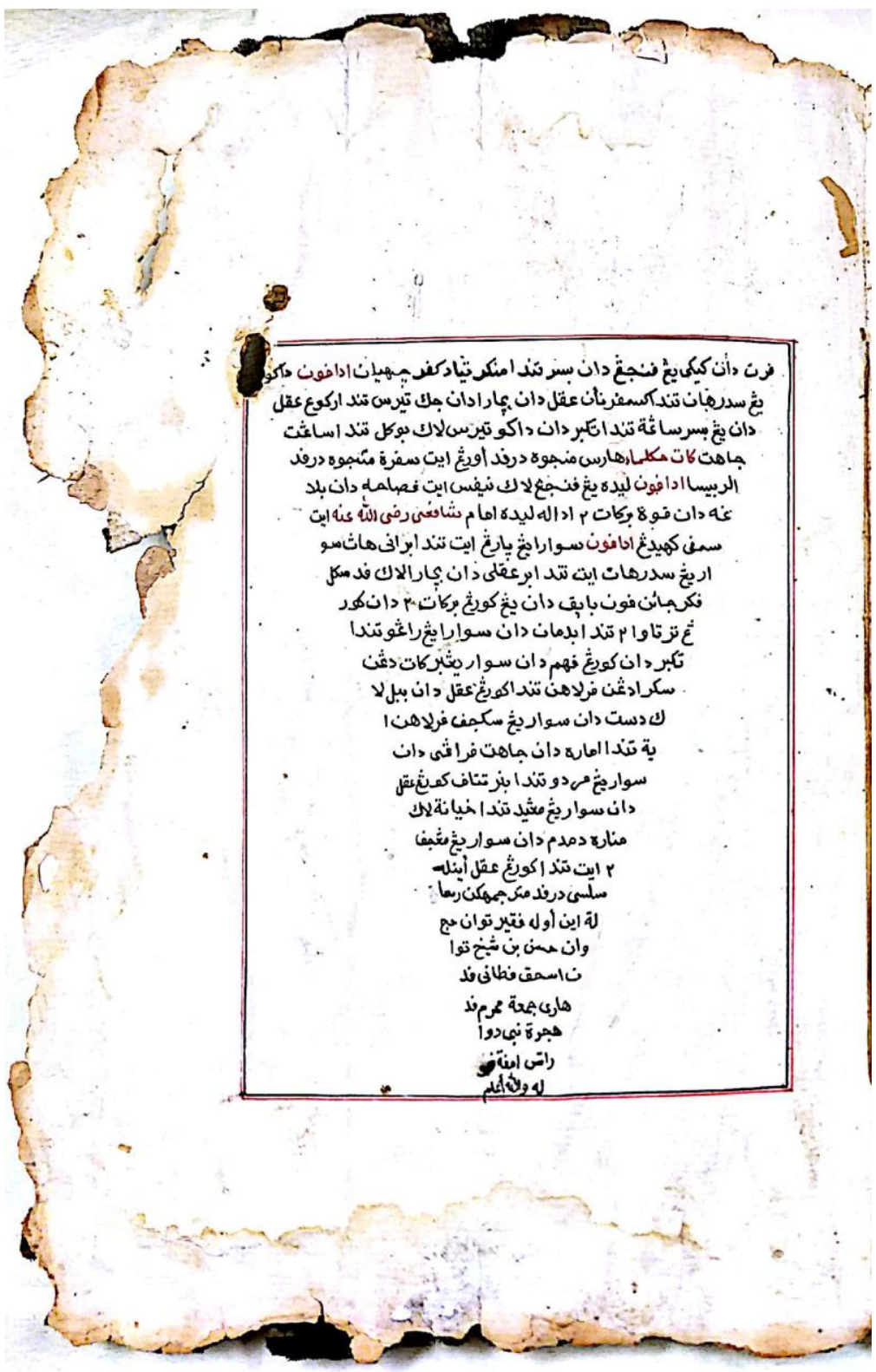


Rajah 2: Halaman 30 manuskrip yang merupakan permulaan Kitāb al-Fa'al

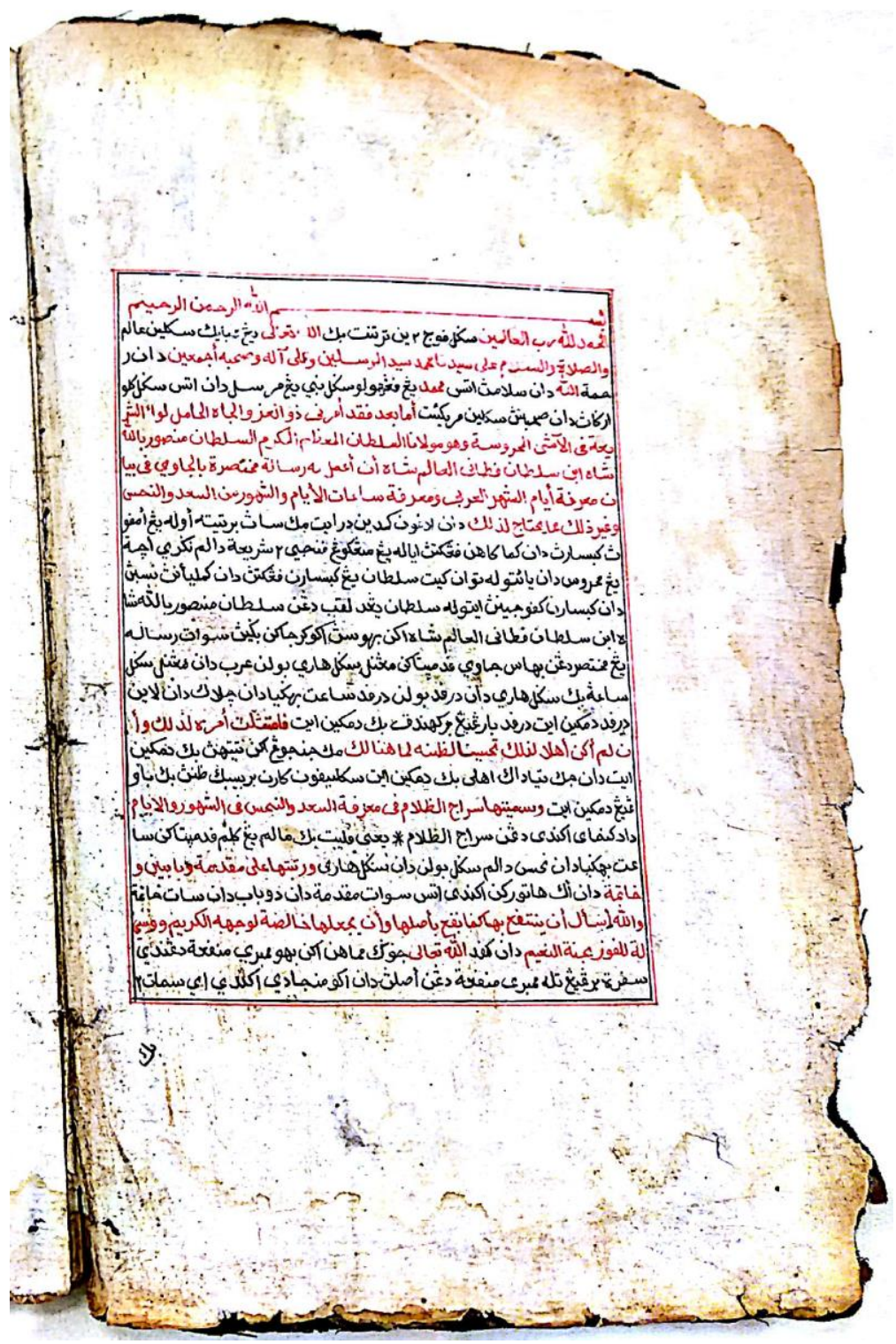


Rajah 3: Halaman 84 dan terakhir manuskrip

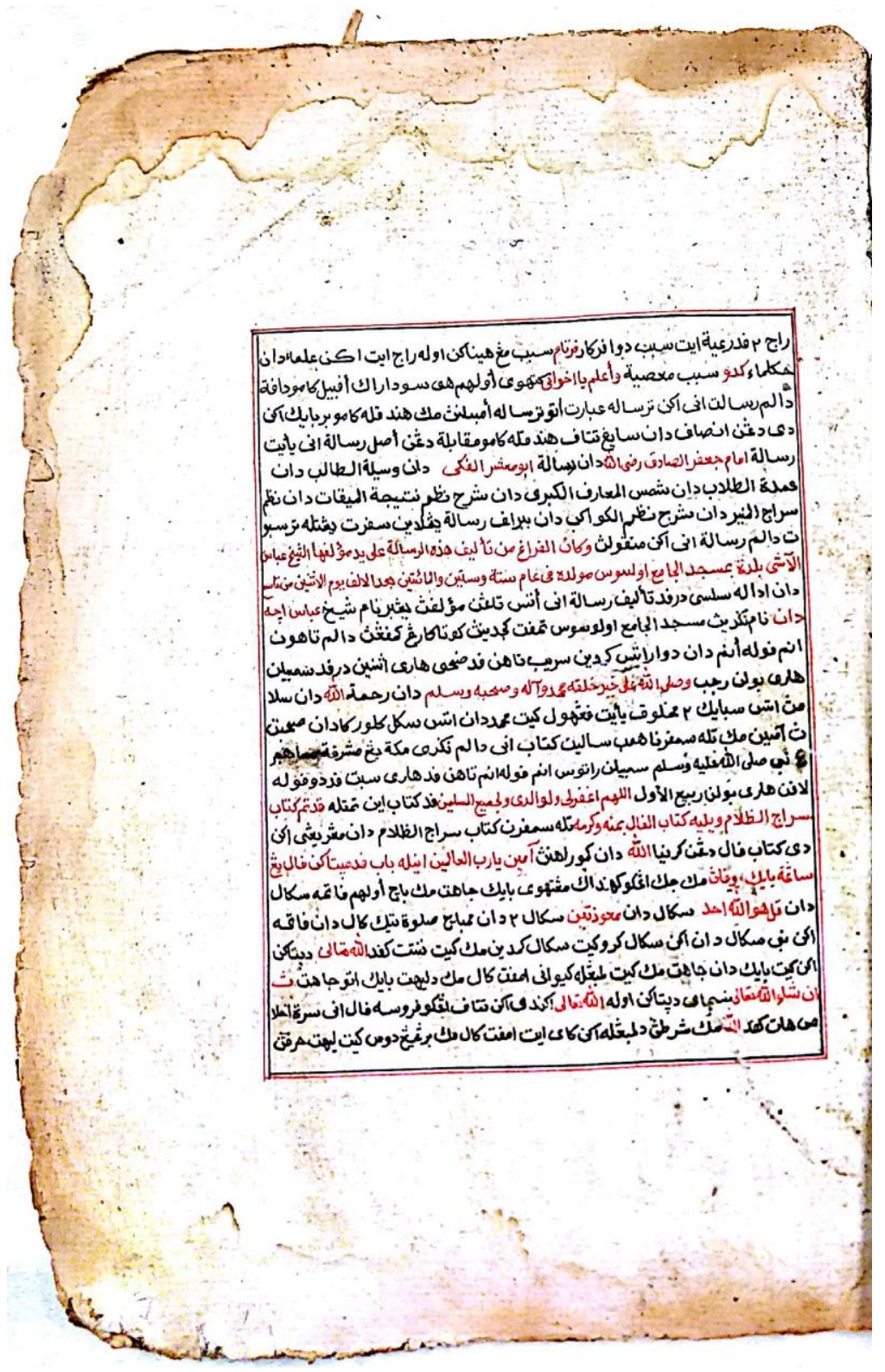


Setelah kira-kira setengah abad di Mekah, Wan Hasan bin Wan Ishak pulang ke tanah air meninggalkan saudara kandungnya, Wan Ali yang bercadang menetap di Mekah. Kerana bercadang menghabiskan sisa-sisa hidupnya di kota suci tersebut, Wan Ali bin Wan Ishak membeli rumah dan mula membina keluarga di sana dengan mengahwinkan dua anak perempuannya dengan dua tokoh ilmuan Melayu, iaitu Nik Mat Kecik al-Fatani dan Nik Muhammad bin Tuan Abdullah Kerisik (juga dikenali dengan gelaran Nik Mat Besar). Tatkala sampai di Patani kira-kira pada 1950, Wan Hasan mendapati Patani dan Kedah sedang menghadapi 'zaman payah' akibat kalah dalam beberapa siri pemberontakan 1831-1840M melawan kerajaan Siam Senggora. Ramai rakyat Patani melarikan diri akibat benci kerana terpaksa duduk dibawah pemerintahan Raja Siam ketika itu. Pada tahun 1842 pula, Kelantan menghadapi pergolakan akibat perang saudara yang berlarutan beberapa tahun. Kekalutan politik di utara semenanjung ini menyebabkan Syeikh Wan Hasan bin Wan Ishaq berpindah ke daerah Besut, Terengganu. ${ }^{11}$

Di Besut, beliau sangat dihormati dan kedatangan beliau disambut baik oleh Tengku Abdul Kadir ibni Sultan Mansur I yang merupakan Raja Besut di bawah kekuasaan Sultan Terengganu ketika itu. Sebagai menghargai kedudukan beliau, Istana telah melantik Wan Hasan sebagai penasihat Raja Besut dan masyarakat pula menganggap beliau sebagai 'guru pertama' mereka. ${ }^{12} \mathrm{Hal}$ ini menyebabkan gelaran beliau sebagai Tuan Hasan Besut terkenal sehingga ke pulau Sumatera dan institusi pondok yang dibinanya di Kampung Palembang (dalam Kampung Raja) mendapat tarikan paling ramai masyarakat berbanding institusiinstitusi pondok yang lain. Di samping menjadi penasihat Sultan

11 Ibrahim Syukri, Sejarah Kerajaan Melayu Patani (Bangi: Penerbit Universiti Kebangsaan Malaysia, 2005), 82-90; Wan Mohd Shaghir, Penyebaran Islam \& Silsilah Ulama Sejagat Dunia Melayu, 39-40; Ahmad Fathy, Ulama Besar dari Patani, 251; Mohd Ekhbar Daud \& Farid Mat Zain, "Peranan Ulama dalam Perkembangan Islam di Besut, Terengganu: Satu Pemerhatian Awal", Jurnal AL-ANWAR, Persatuan Bekas Mahasiswa Islam Timur (PBMITT) 1, no.3 (2017), 105.

12 Ahmad Fathy, Ulama Besar dari Patani, 251; Muhammad Abu Bakar, Ulama Terengganu Suatu Sorotan (Kuala Lumpur: Utusan Publication \& Distributors Sdn. Bhd., 1991), 63-64. 
dan mengajar ilmu di pondok persendirian, beliau juga dilantik sebagai imam di Masjid Raja, Besut. ${ }^{13}$

Wan Mohd Shaghir meriwayatkan dari tok-tok guru Patani bahawa Tuan Hasan Besut bin Wan Ishaq sangat mahir akan ilmu kebatinan di samping merupakan seorang pengamal perubatan tradisional yang pintar. ${ }^{14}$ Dikatakan bahawa walaupun beliau mendapat penghormatan tinggi dari pihak Istana dan masyarat, namun Wan Hasan bin Wan Ishaq tidak pernah meninggi diri dan tidak memilih bulu dalam bergaul. Tuan Hasan Besut wafat pada tahun 1280H/1863M dan jenazahnya dikebumikan di Tanah Perkuburan Islam Kampung Palembang, Besut. Walaupun tidak meninggalkan anak, namun jasa Tuan Hasan Besut tetap kekal dengan meninggalkan karya-karya bermanfaat dan para pelajar yang kemudiannya meneruskan usaha mendidik masyarakat melalui sistem pondok seperti Tuan Guru Haji Husin Kampung Lapu dan Haji Said Kampung Lama.

\section{Karya Hidāyat Al-Mukhtār dan Data Semakan}

Hidāyat al-Mukhtār atau nama penuhnya Hidāyat al-Mukhtār fì Faụl Talab al-'Ilm wa Faụl Șāhibihi min Kalām Sayyid al-Akhyār merupakan sebuah karya yang penting dunia Melayu dalam bidang Hadis. Sebilangan pengkaji seperti Ahmad Fathy dianggap telah terkeliru apabila menyatakan secara eksplisi bahawa karya ini adalah karya terjemahan Hadis 40 yang dihimpunkan oleh alNawāwī. ${ }^{15}$ Hakikatnya, karya ini, seperti yang dinyatakan secara jelas oleh pengarangnya, merupakan karya terjemahan Hadis 40 yang dikumpulkan oleh al-Mundhiri. ${ }^{16}$

Al-Mundhirī merupakan seorang ulama Hadis yang disegani di Mesir pada abad ke $7 \mathrm{H} / 13 \mathrm{M} .{ }^{17}$ Beliau mempelajari ilmu

${ }^{13}$ Mohd Ekhbar Daud \& Farid Mat Zain, Perkembangan Awal Islam di Besut, Terengganu (Prosiding Kolokium Antarabangsa Siswazah Pengajian Islam (KASPI), 2015), 216-217.

14 Wan Mohd Shaghir Penyebaran Islam \& Silsilah Ulama Sejagat Dunia Melayu, 40-41.

15 Ahmad Fathy, Ulama Besar dari Patani, 252.

16 Wan Hasan al-Fatani, Hidāyat al-Mukhtār fì Faḍl Talab al-'Ilm wa Faḍl Săhabihi min Kalām Sayyīd al-Akhyār (t.tp: t.pt, t.t), 2.

17 Shams al-Dīn Muhammad ibn Aḥmad al-Dhahabī, Siyār A 'lām al-Nubalā', ed. Bashshar 'Awwad Ma'ruf \& Muhy al-Dīn Hilal al-Sarhan (Cet. 11, Beirut: Mu'assasah al-Risālah, 1996), 321. 
al-Qira'at dari al-Artahi, mempelajari ilmu Fiqh dari Abu alQasim 'Abd al-Rahmān al-Qurāsh̄̄, mempelajari ilmu Bahasa dan Sastera dari 'Alī Abū al-Ḥusayn Ibn Yahyāa al-Naḥwī̄ dan melazimi serta meriwayatkan hadis dari ulama yang sangat ramai. Sebilangan besar mereka telah disenaraikan oleh alDhahabī dan al-Safadī dalam kitab al-Siyār dan al-Wāfit. ${ }^{18}$ Kerana penghormatan ulama Mesir kepadanya, al-Mundhirī yang juga dikenali sebagai Zākī al-Dīn, telah dilantik sebagai pemimpin ulama Dār al-Ḥadīth al-Kāmiliyyyah di Keherah selama kira-kira 20 tahun. Kesimpulannya, al-Mundhirī merupakan ulama Hadis yang sangat dihormati oleh ulama zamannya. Al-Dhahabī telah meriwayatkan pelbagai riwayat yang menjadi bukti penghormatan yang diterima beliau seperti riwayat al-Hafiz Izz al-Dīn al-Husaynī dan alDimyatī. Berkata Izz al-Dīn dalam salah satu ucapannya:

$$
\text { كان شيخنا زكي الدين عالما بصحيح الحديث وسقيمه، ومعلوله وطرقه، }
$$

Terjemahan: "Guru kami, Zākī al-Dīn merupakan seorang yang sangat arif berkenaan hadis-hadis sahih, da'if dan ma'lul berserta sanad-sanadnya. Pengetahuan beliau luas dalam halhal mengenai hukum, makna berserta isu permasalahannya selain tahu maksud perkataan-perkataan ganjil, i'rab dan variasi lafaznya. Beliau merupakan seorang imam dan hujjah (dalam bidang Hadis)" ${ }^{19}$

Hadis 40 yang dihimpunkan al-Mundhirī berkenaan kelebihan menuntut ilmu ini sebuah karya beliau yang tidak diketahui kewujudannya melainkan menerusi terjemahan Tuan Hasan Besut. Berdasarkan tinjauan yang dilakukan oleh pengkaji terhadap kitab-kitab Tarajim seperti al-Siyār, al-Wafi, Dīwān alIslām dan al-A 'lam, pengkaji mendapati pelbagai judul manuskrip yang telah dihasilkan oleh al-Mundhirī seperti al-Targhīb wa alTarhīb, Sharh al-Tanbih, Mukhtașar Muslim dan Mukhtașar Abī $D \bar{a} w \bar{u} d$, namun tidak didapati sebarang pernyataan mengenai

\footnotetext{
18 Șalāh al-Dīn Khalil ibn Aybak, Al-Wāfì bi al-Wafāyāt, ed. Aḥmad al-Arna'ut \& Turki Muștafā (Beirut: Dār Ihyā' al-Turath al-'Arabī, 2000), 19:11.

19 Al-Dhahabi, Siyār A 'lām al-Nubalā', 23: 322.
} 
karya ini, kecuali apa yang nyatakan oleh al-Zirikli bahawa beliau mempunyai karya Hadis $40 .{ }^{20}$ Tetapi pernyataan umum sebegini sebenarnya mengelirukan kerana selain karya Hadis 40 mengenai kelebihan menuntut ilmu, al-Mundhirī juga mempunyai Hadis 40 mengenai perbuatan baik. Sehubungan itu bagi mendapatkan lebih kepastian, pengkaji telah menyemak lebih 30 katalog digital Manuskrip Islam dari seluruh dunia. Data semakan dapat dilihat seperti berikut:

Jadual 1: Katalog-katalog digital yang dirujuk

\begin{tabular}{|c|l|l|}
\hline No. & \multicolumn{1}{|c|}{ Nama Perpustakaan } & \multicolumn{1}{c|}{ Lokasi } \\
\hline 1. & al-Haram al-Makki & Mekah \\
\hline 2. & al-Malik Abd al-Aziz & Riyad \\
\hline 3. & Makkah al-Mukarramah & Mekah \\
\hline 4. & Jami 'Unayzah & Unayzah, Arab Saudi \\
\hline 5. & Al-Maktabah al-Salihiyyah & Unayzah, Arab Saudi \\
\hline 6. & al-Ifta' al-Su'udiyyah & Riyad \\
\hline 7. & al-Jami ah al-Islamiyyah & Madinah \\
\hline 8. & Jami'at al-Malik Su'ud & Riyad \\
\hline 9. & al-Masjid al-Nabawi & Madinah \\
\hline 10. & $\begin{array}{l}\text { Muhammad ibn 'Abd Allah } \\
\text { Al 'Abd al-Qadir }\end{array}$ & Al-Ahsa', Arab Saudi \\
\hline 11. & Al-Azhariyyah & Kaherah \\
\hline 12. & Dar al-Kutub al-Misriyyah & Kaherah \\
\hline 13. & Masjid Al-Sayyidah Zaynab & Kaherah \\
\hline 14. & Al-Taymuriyyah & Kaherah \\
\hline 15. & Baladiyyat al-Iskandariyyah & Iskandariah \\
\hline 16. & Perpustakaan El Escorial & Madrid \\
\hline 17. & Dar al-Kutub al-Qatariyyah & Qatar \\
\hline 18. & Perpustakaan Chester Beatty & Dublin \\
\hline 19. & Al-Zahiriyyah & Damsyik \\
\hline 20. & Maktabat al-Ahqaf & Yaman \\
\hline 21. & $\begin{array}{l}\text { Repositori Wizarat al-Awqaf } \\
\text { al-Kuwaytiyyah }\end{array}$ & Kuwait \\
\hline 22. & Repositori Markaz Najibawayh & Sarajevo \\
\hline 23. & Gazi Husrev-beg & Sarajevo \\
\hline 24. & Universiti Leipzig & Leipzig \\
\hline 25. & Universiti Albert Ludwigs & $\begin{array}{l}\text { Freiburg im Breisgau, } \\
\text { Jerman }\end{array}$ \\
\hline & & \\
\hline
\end{tabular}

${ }^{20}$ Khayr al-Dīn al-Zirikli, al-A 'lam (Beirut: Dār al-'Ilm li al-Malāyīn, 2002), $4: 30$. 


\begin{tabular}{|c|l|l|}
\hline No. & \multicolumn{1}{|c|}{ Nama Perpustakaan } & \multicolumn{1}{c|}{ Lokasi } \\
\hline 26. & Universiti Tokyo & Tokyo \\
\hline 27. & American University & Beirut \\
\hline 28. & Universiti Princeton & New Jersey \\
\hline 29. & $\begin{array}{l}\text { Repositori al-Shaykh Hamdi } \\
\text { al-Salafi }\end{array}$ & Kurdistan, Iraq \\
\hline 30. & Al-Maktabat al-Qasimiyyah & Sind, Pakistan \\
\hline
\end{tabular}

Meskipun carian melalui katalog-katalog digital manuskrip Arab-Islam seluruh dunia ini telah melebihi 30 unit, namun ia tidak membuahkan hasil. Semakan tidak menemukan manuskrip Hadis 40 mengenai kelebihan menuntut ilmu yang ditulis oleh alMundhirī. Berdasarkan data ini, pengkaji menyimpulkan bahawa karya tersebut merupakan salah sebuah karya Islam yang hilang dan hasil terjemahan Tuan Hasan Besut merupakan satu-satunya jalan yang mampu memberi kita informasi berkenaan karya alMindhirī berkenaan. Sehubungan itu, dapat dibuktikan bahawa ia merupakan karya nadir yang sangat penting dalam bidang pengajian Hadis.

Wan Mohd Shaghir menjelaskan bahawa karya Hidāyat alMukhtār telah dicetak beberapa kali, iaitu dibahagian akhir kitab Tãj al-Mulūk dan dibahagian margin kitab Badī'al-Samāwāt wa al-Arḍ oleh Nuruddin al-Raniri (1309H/1892M). Pada tahun 2003, Khazanah Fathaniyah, Kuala Lumpur telah mengulang cetak (fotokopi) sebuah cetakan tunggal karya Hidāyat al-Mukhtār. Cetakan ini dianggap sebagai cetakan paling penting kerana ia merupakan cetakan pertama bertarikh 7 Jamadil Awal 1249H/ 28 September 1883M (kira-kira 4 bulan setelah karya diselesaikan oleh Tuan Hasan Besut pada 6 Muharam 1249H/25 Mei 1833M). Percetakannya dilakukan berpandukan sebuah naskhah manuskrip milik Abdul Aziz bin Ismail bin Lebai Jamaluddin al-Kalantani. Walau bagaimanapun, cetakan ini mempunyai banyak kesalahan bahasa dan penyalinan, disamping tidak diketahui identiti syarikat percetakan yang bertanggungjawab menerbitkannya. Manuskrip asal (tulisan tangan Tuan Hasan Besut) tidak ditemui hingga hari ini, walau bagaimanapun berdasarkan satu maklumat tidak rasmi yang diperoleh pengkaji, manuskrip asli (tulisan tangan pengarang) bagi karya Hidāyat al-Mukhtār tersimpan di Beyazit State Library di Istanbul dengan kod 892. Tetapi sehingga hari ini, pengkaji tidak berjaya mendapatkan sebarang maklumat mengenai manuskrip berkod 892 kerana pihak perpustakaan Beyazit State 
tidak menyediakan sebarang katalog digital di samping berurusan dengan mereka melalui atas talian (online) adalah sukar.

\section{Hasil Penyelenggaraan Teks}

Berikut merupakan teks karya Hidāyat al-Mukhtār berdasarkan edisi cetakan pertama yang bertarikh 7 Jamadil Awal 1249H/28 September 1883M (fotokopi terbitan Khazanah Fathaniyah, Kuala Lumpur). Memandangkan saiz karya terlalu besar untuk dimuatkan dalam artikel ini, dan penerbitan penuh teks telah dipersetujui untuk dibuat di Khazanah Fathaniyah, maka pengkaji hanya akan memaparkan sebahagian kecil teks karya, iaitu bahagian doxology (muqaddimah), 5/40 kandungan hadis dan colophon). Metode yang digunakan adalah metode transliterasi Gaya UKM, tetapi tidak menggunakan font Furatech. Teks yang ditambah oleh pengkaji pada teks karya diletakkan antara dua Kurungan Siku [ ], sedang ulasan dan kritikan teks pula diletakkan pada bahagian nota kaki bagi memudahkan rujukan.

Sabda Nabi SAW:

$$
\text { صَالِحِّ يَدْعُو لَهُ، }
$$

Terjemah Hadis Arba 'in:

Inilah kitab yang bernamakan dia 'Hidāyat al-Mukhtār' ertinya dan aku namai akan dia pertunjukan Tuhan yang Mukhtar, menterjemahkan daripada Hadis Arba'in, pada menyatakan kelebihan men[un]tut ilmu dan kelebihan empunyanya yakni orang yang menanggungnya daripada perkataan penghulu bagi segala orang pilihannya yakni Nabi salla Allah 'alayhi wa sallam dari pada menterjemahkan ini oleh faqir Tuan Haji Wan Hasan ibn Tuan Syeikh Ishaq Fatani nafa 'ana Allah Ta 'ala, Amin. (1 a)

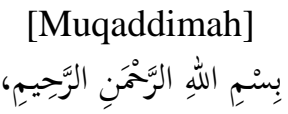

Dengan nama Allah yang amat pemurah akan segala hambanya yang mu'min dan yang kafir di dalam negeri Dunia ini, lagi yang amat mengasihani bagi segala hambanya yang mu'min di dalam negeri Akhirat, aku memulai risalah ini

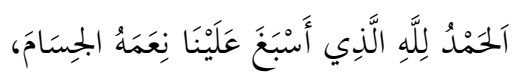


ertinya bermula segala puji-pujian itu bagi Allah, Tuhan yang mengurniai ia atas kami akan beberapa nikmat-Nya yang besarbesar.

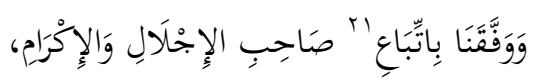

ertinya dan telah memberi tawfiq ia akan kita dengan mengikut nabi-Nya yang mengu[r]niai kebesaran dan kemuliaan.

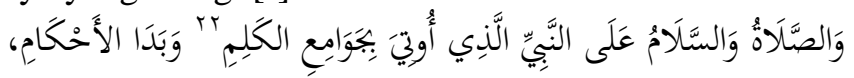

ertinya dan bermula rahmat Allah dan selamanya atas yang didatangkan dengan jawāmi al-kalim dan dengan segala yang indah-indah dari pada hukum.

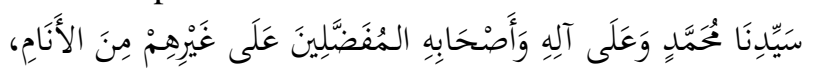

ertinya iaitu penghulu kita Muhammad dan atas segala keluarganya dan segala sahabatnya yang dilebihkan akan mereka itu atas yang lainnya dari segala manusia.

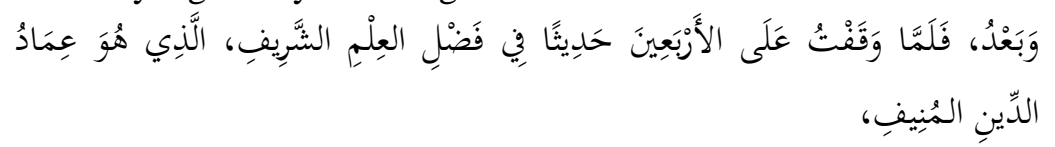

ertinya dan adapun kemudian dari pada itu maka tatkala berhenti aku ertinya tatkala mentala'ah atas empat puluh hadis pada menyatakan kelebihan ilmu yang mulia yang ialah tiang agama yang amat tinggi.

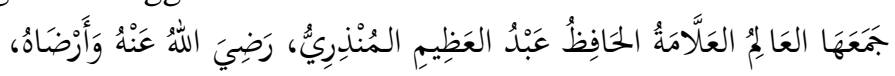

ertinya meng[h]impunkan akan dia oleh yang 'alim lagi 'allamah lagi yang hafiz 'Abd al-'Az̄ìm al-Mundhirī telah redha Allah Taala daripadanya dan meredhai akan dia.

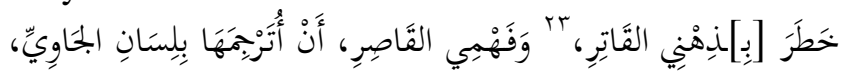

21 Pada teks asal terdapat tambahan perkataan niyyah yang mungkin merupakan tahrif (typo) bagi perkataan sunnah. Namun tidak didapati sebarang terjemahan bagi perkataan tersebut pada teks terjemahan.

22 Begini teks asal dengan tambahan harf al-jarr (ba') pada perkataan jawāmi , namun kaedah bahasa Arab yang tepat adalah tanpa harf kerana perbuatan 'ūtiya yu'tī bersifat muta 'addi dengan sendirinya, yakni tanpa harf al-jarr seperti yang didapati pada firman Allah SWT dalam Surah al-Isrā':71 dan Surah al-Qașaș:48.

23 Dalam teks asal dhihnī tanpa harf al-jarr, tetapi gaya bahasa Arab menentukan harus diletakkan harf al-jarr (bihi) atau (fihi) atau ('alayhi), 
ertinya tatkala terhentilah aku atas yang tersebut ayat, terlintaslah oleh zihnku yang lemah ${ }^{24}$ dan fahamanku yang pendek bahawa aku hendak terjemahkan akan dia dengan bahasa Jawi.

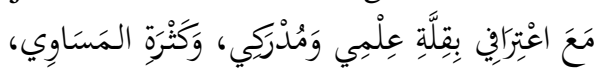

ertinya serta mengakulah aku dengan sedikit ilmuku dan pendapatanku dan dengan banyaklah kesalahan ku

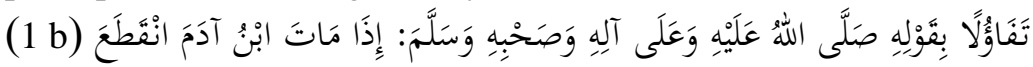

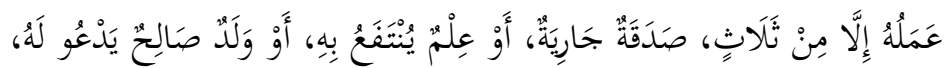

ertinya kerana mengambil sempena dengan sabda Nabi salla Allah 'alaihi wa ala alihi wa shahbihi wa sallam: "Apabila matilah anak Adam nescaya putuslah amalannya melainkan daripada tiga perkara, pertamanya sedekah yang berlaku ia, ertinya berbuat waqaf yang berpanjangan ia, keduanya ilmu yang diambil manfaat dengan dia, ketiganya anak yang salih yang mendoakan baginya”.

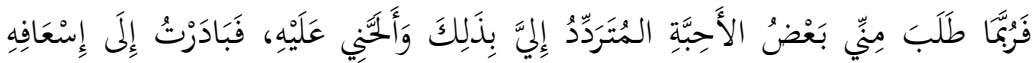
عَلَّى ذَلِكَكَ،

ertinya maka terkadang men[un]tu[t]nya daripada aku oleh setengah daripada segala kekasihku yang pergi datang ia kepada aku dengan demikian itu serta menyungguh-nyungguh akan daku atasnya, maka bersegeralah aku kepada menolongkan atas demikian itu

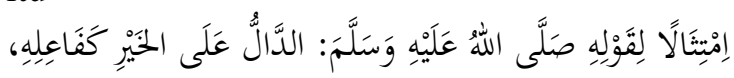

ertinya kerana menyenggarakan ${ }^{25}$ bagi kita $\left[\right.$ sabda $^{26}$ Nabi salla Allah 'alayhi wa sallam: "Bermula orang yang menunjukkan atas kebajikan itu seperti orang yang berbuat dia".

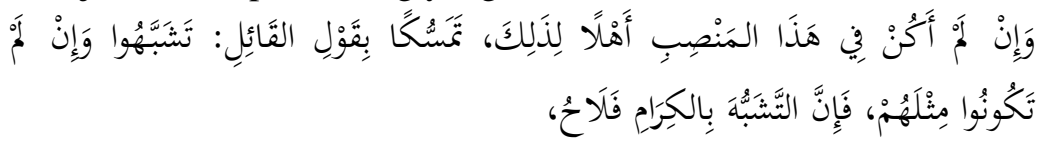

kerana khațir tidak bermuta'addi kecuali dengan salah satu dari ketiga-tiga harf al-jarr tersebut.

${ }^{24}$ Pada teks asal, perkataan "lemah" mengalami tahrif dan ditulis lūqah.

25 Tidak dapat dipastikan apakah maksud perkataan

$$
\text { ميغكر اكن }
$$

pada teks asal, namun maksud perkataan imtithālā dalam konteks ayat di atas adalah "menurut" atau "menyempurnakan".

26 Perkataan ini gugur pada teks asal, dan ia ditambah berdasarkan teks Arab. 
ertinya dan jika tiada daku pada bahagian ini ahli bagi demikian itu sekalipun kerana aku berpegang dengan perkataan orang yang berkata, yakni orang yang bersyair, iaitu: "Menyerupailah kamu jika tiada kamu s[er]upa mereka itu, maka dari kerana bahawasanya menyerupai dengan orang yang mulia itu beroleh kemenangan".

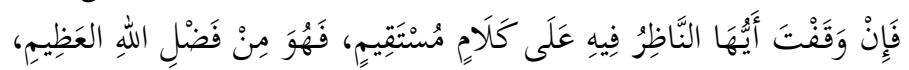

ertinya maka jika terhenti engkau hai orang yang menilik padanya atas perkataan yang betul, maka iaitu semata-mata kerananya Allah subhanahu wa ta'ala yang melengkapi ia.

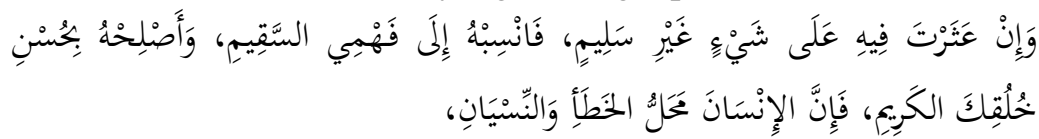

ertinya dan jika engkau dapat padanya atas sesuatu yang tiada sejahtera ia maka bangsakan olehmu kepada fahamku yang sakit ia faham itu dan baiki olehmu akan dia dengan keelokan perangai engkau yang mulia, maka dari kerana bahawasanya manusia itu tempat tersalah dan tempat kelupaan.

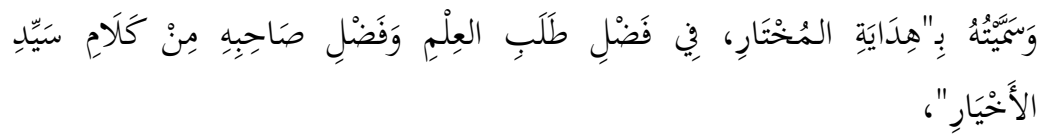

ertinya aku namai akan dia Pertunjukan bagi Tuhan yang Mukhtar pada menyatakan kelebihan menuntut ilmu dan kelebihan mempunyai yakni orang yang menanggungnya ( 2 a) daripada perkataan penghulu bagi segala orang yang pilihan yakni Nabi salla Allah 'alayhi wa sallam.

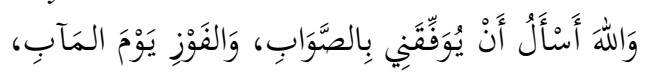

ertinya dan akan Allah Taala aku memohonkan bahawa memberi tawfiq ia akan daku dengan yang betul dan akan kemenangan pada hari kembali, iaitu hari Kiamat.

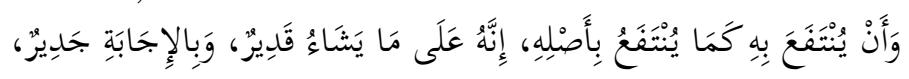

ertinya dan aku pohonkan kepada-Nya bahawa memberi manfaat ia dengan dia seperti barang yang memberi manfaat dengan asalnya, dari kata bahawasanya Allah subhanahu wa ta'ala atas barang yang men[gke]hendaki amat kuasa dan dengan memperkenankan amat sebenar-benar. 


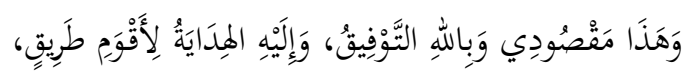

ertinya dan bermula itulah maksudku dan dengan Allah pe[r]tolong[an] dan kepadanya pertunjuk bagi yang terlebih betul daripada jalan bermula.

Hadis yang Pertama

Diceritakan daripada 'Abd Allah ibn 'Abbas radiya Allah 'anhu telah berkata ia: Telah bersabda Nabi salla Allah 'alayhi wa sallam:

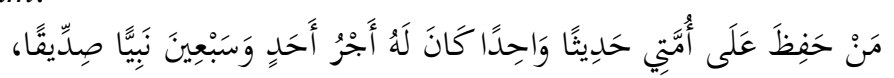

ertinya "Barang siapa menghafazkan atas umatku akan hadis yang satu nescaya ia adalah baginya pahala 71 nabi yang siddiq". Ketahui olehmu hai saudaraku dan adalah yang dikehendaki dengan orang yang menghafazkan ayat, orang yang memindahkan dan menyampaikan kepada saudaranya yang muslim dan juga tiada hafaz ia dan tiada mengetahui akan maknyanya sekalipun dari kerana dengan dialah hasil mengambil manfaat oleh segala muslimin dengan bersalahan orang yang menghafazkan dan tiada memindahkan kepada mereka itu dan maknanya. Barang siapa memindahkan yakni menyampaikan atas umatku suatu hadis, nescaya adalah baginya pahala 71 nabi yang siddiq.

\section{Hadis yang Kedua}

Diceritakan daripada Sayyiduna Bara' ibn 'Azib radiya Allah anhu, telah bersabda Nabi salla Allah 'alayhi wa sallam:

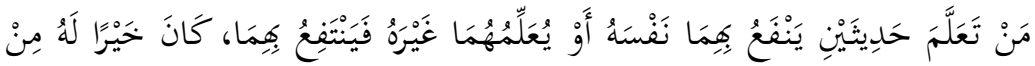
عِبَادَةٍ سِتِّينَ عَامًا،

ertinya "Barang siapa yang memperlajarkan akan 2 hadis yang memberi manfaat ia dengan keduanya akan dirinya, atau mengajari akan keduanya orang yang lainnya maka mengambil manfaat ia dengan keduanya, nescaya adalah terlebih baik baginya daripada berbuat ibadat 60 tahun".

Bermula Hadis yang Ketiga

Diceritakan akan daripada Abu Umamah al-Bahili radiya Allah 'anhu, telah berkata ia: Telah bersabda Rasulullah salla Allah 'alayhi wa sallam: 


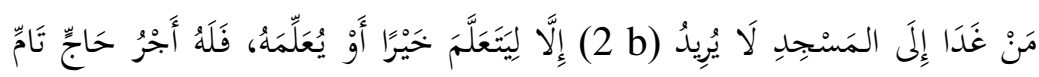
الخجَّةِ،

ertinya "Barang siapa berpagi-pagi ia kepada masjid tiada meng[ke]hendaki ia melainkan kerana mempelajari akan kebajikan, atau mengajari ia akan dia maka baginya itu pahala orang yang haji yang sempurna hajinya”.

Bermula Hadis yang Keempat

Diceritakan daripada Abu Umamah radiya Allah 'anhu berkata ia, telah bersabda Rasulullah salla Allah 'alayh wa sallam:

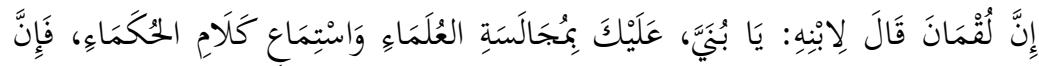

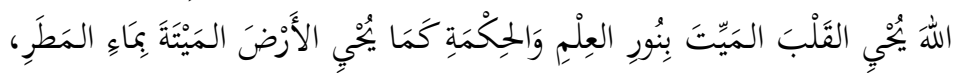

ertinya "Bahawasanya Luqman al-Hakim berkata ia bagi anaknya: hai anakku, lazimkan olehmu akan diri engkau dengan sekedudukan bagi segala ulama dan mendengarkan perkataan segala hukama' bahawasanya Allah ta'ala menghidupkan ia akan hati yang mati dengan cahaya ilmu dan hikmah seperti barang yang menghidup ia akan bumi yang mati dengan air hujan".

Bermula Hadis yang Kelima

Diceritakan daripada Anas ibn Malik radiya Allah 'anhu berkata ia: Telah bersabda Rasulullah salla Allah 'alayh wa sallam:

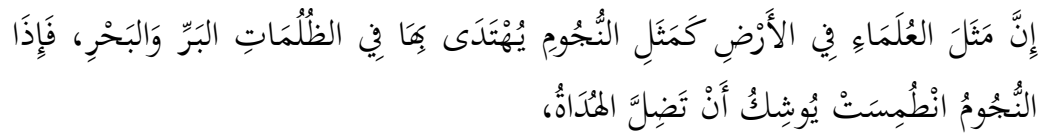

ertinya "Bahawasanya seu[m]pama segala ulama pada bumi itu seperti seu[m]pama segala bintang di langit beroleh pertunjuklah dengan dia pada segala kelam darat dan laut, maka apabila segala bintang itu terhempas ia, yakni hilang ia, hampirlah bahawa sesat oleh segala orang yang menunjuk itu".

[Sekadar ini teks doxology dan kandungan hadis yang dipaparkan sebagai contoh... Manakala teks penutup dan colophon...]

Inilah akhir hadis yang empat puluh. Tamat.

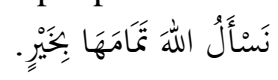

Ini suatu tatimmah yakni suatu kesempurnaan kami pohonkan akan Allah subhanahu wa ta'ala akan sempurnaa[a]nnya dengan kebajikan. Ketahui oleh mu hai saudaraku bahawasanya sekalian 
hadis yang datang pada menyatakan kelebihan ilmu dan kelebihan orang yang alim itu jika ia menuntut ilmu itu kerana wajh ${ }^{27}$ Allah Taala serta mengamali ia akan barang yang ia ketahuinya. Dan jikalau satu 'ushur' ${ }^{28}$ sekalipun seperti berkata sahib al-Zubad rahimahu Allah ta' 'ala:

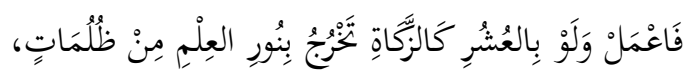

ertinya "Maka amal oleh mu dan jikalau dengan satu 'ushur sekalipun seperti zakat, nescaya keluarlah engkau dengan cahaya ilmu itu daripada segala kelam jahil" tiada kerana riya' dan sum 'ah dan tiada pula kerana suatu gharad daripada gharad di dunia, baharulah mencapai ia akan fadhilah ini dan masuklah di dalam kepujian itu. Adapun jika ia menuntut kerana dipuji orang yang akan dia atau kerana riya ' dan sum'ah atau kerana membantahi akan orang atau kerana bermegah-megah ia setengah atas setengahnya atau kerana suatu gharad daripada gharad dunia seperti hendak tipu-daya dengan dia akan $\mathrm{itu}^{29}$ segala manusia atau kerana menambahi pangkat dan darjat pada raja-raja dan orang yang besar-besar, atau tiada ia mengamalkan barang yang ia ketahui dan jikalau satu 'ushur sekalipun, maka adalah menuntut ilmu seperti yang tersebut itu tiada ada bahayanya melainkan atasnya dan tiada ada faedahnya melainkan pada dunia juga, seperti firman Allah Taala:

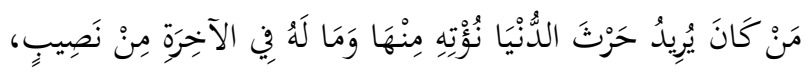

ertinya "Barang siapa adalah ia menghendaki perha'an ${ }^{30}$ dunia nescaya kami datangkan akan dia daripada dunia [dan] tiadalah baginya di dalam akhirat daripada bahagian, dan sabda Nabi shalla Allah alayhi wa sallam:

27 Perkataan ini secara literalnya bermaksud "wajah" iaitu muka, namun kerana ia dinisbahkan kepada Allah yang kita imani sebagai "tiada bagiNya sebarang tamsilan dengan apapun" [al-Shura: 11], maka sebilangan ulama mentafsirkannya secara majazi (kiasan) dengan makna "reda".

28 Bermaksud 'satu persepuluh' $(1 / 10)$.

29 Perkataan "itu” pada teks asal mengalami tahrif kerana ditulis 'ut.

30 Perkataan farha'an pada teks asal ini tidak diketahui maknanya, namun maksud perkataan Arab harth adalah "tanaman" yang memberi makna "pahala" secara isti "arah atau kiasan. 


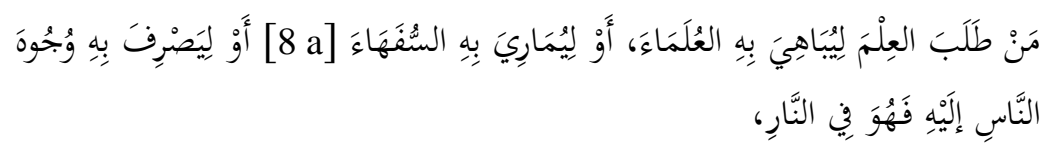

ertinya "Barang siapa menuntut akan ilmu kerana memegahmegah dengan dia akan segala ulama atau kerana membembantahi dengan dia akan segala orang yang $\operatorname{safih}^{31}$ atau kerana hendak memengalingkan dengan dia akan segala muka manusia kepadanya, maka ia itu di dalam neraka dan pada satu riwayat di masukkan dia oleh Allah Taala di dalam neraka jahanam", dan lagi sabdanya:

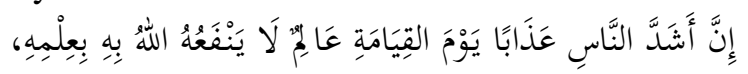

ertinya "Bahawasanya yang terlebih sangat baik segala manusia itu siksa pada hari Kiamat ia itu orang yang alim yang tiada memberi akan dia [manfaat] ${ }^{32}$ oleh Allah Taala dengan ilmunya", dan lagi sabdanya:

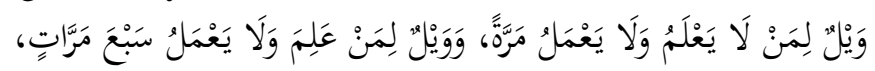

ertinya "Celaka bagi orang yang tiada mengetahui dan tiada me[ng]amal ia sekali, dan celaka bagi orang yang mengetahui dan tiada me[ng]amal akan dia tujuh kali", hingga akhir beberapa hadis pada mencercakan segala ulama $\mathrm{al}-\mathrm{Su},{ }^{33}$ dan perkataan ulama yang 'amilin yang [muradkan dan masdar] ${ }^{34}$ ini daripada atsar dan perkataan ulama. Memada[i]lah bagi orang yang beroleh tawfiq dan hidayah itu ulama.

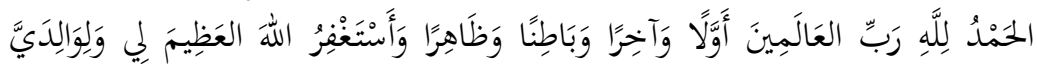

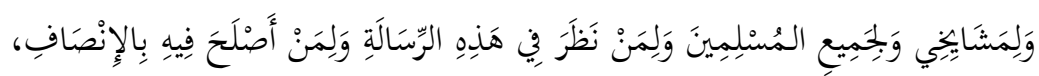

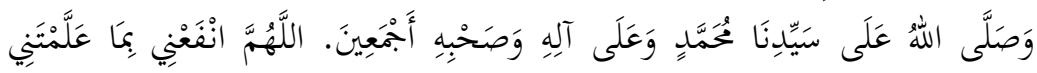

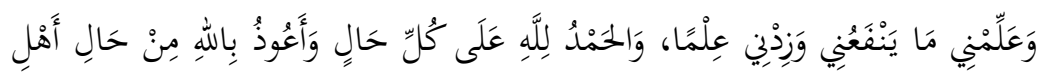

${ }^{31}$ Safih merupakan perkataan pinjaman dari Bahasa Arab yang bermaksud orang jahil.

32 Perkataan ini gugur pada teks asal, dan tambahan berdasarkan teks Arab.

33 Bermaksud ulama yang jahat.

34 Murād pada teks bermakna "yang dimaksudkan", manakala mașdar bermaksud "sumber". Walau bagaimanapun, ayat ini tidak begitu jelas maksud sebenarnya bagi pengkaji. 


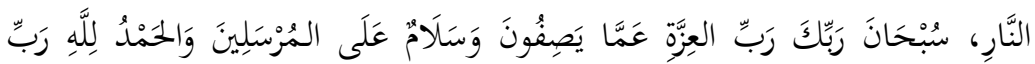 العَالَمِينَ.}

Telah selesai daripada menterjemah ini al-Faqir Tuan Haji Wan Hasan bin Tuan Syeikh Ishaq Fatani pada hari Jumaat pada waktu duha 6 liku hari bulan Muharram pada hijrah Nabi 1249 tahun (25 Mei 1833) di dalam negeri Mekah al-Musyarrafah.

$$
\text { زَادَهَا اللهُ تَعَالَى شَرَفًا وَكَكَمًا. }
$$

Selesailah daripada menyurat risalah ini daripada hari Jumaat akhir Zuhur 7 hari bulan Jumadi al-Awwal (28 September 1833)

$$
\text { عَلَى يَلِ مُطِيعِ اللِهِ ابْنِ فَضْلِ اللهِ عَفَى اللهُ عَنْهُمَا. }
$$

Yang empunya asal naskhah itu al-akh al-kamil Abdul Aziz ibn Ismail bin Lebai Jamaluddin Kalantani.

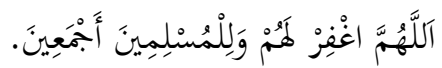

\section{Penutup}

Khazanah manuskrip dan karya-karya nadir sangat penting dalam usaha memperkenalkan negara di peringkat antarabangsa. Karyakarya nadir khususnya berpotensi menjadi produk pelancongan negara yang unggul jika dimanfaatkan sebaiknya. Termasuk karya-karya nadir yang dinyatakan adalah karya Hidāyat alMukhtār fì Faḍl Ṭalab al-'Ilm wa Fạ̣l Șāhibihi min Kalām Sayyid al-Akhyār yang dihasilkan oleh Tuan Hasan Besut. Ini kerana ia berjaya mengharungi gelombang zaman dan badai permodenan, sehingga tampil menyelamatkan sebuah karya yang telah hilang yang ditulis oleh al-Ḥâfiz al-Mundhirī pada abad ke-7H/13M. Walaupun edisi cetakan pertamanya mempunyai pelbagai kesalahan bahasa dan percetakan, namun ia tetap penting kerana menyimpan khazanah keilmuan Islam dan Melayu, selain memelihara athār yang dinisbahkan kepada Rasulullah s.a.w. Sehubungan itu, pengkaji mencadangkan agar athār ini terus dikaji, ditakhrij, dikritik sanad dan matannya selain dijalankan Analisis Kandungan (Content Analysis). Ini kerana di samping menghidangkan informasi-informasi keimanan yang dinisbahkan kepada junjungan kita, Nabi Muhammad SAW, karya ini juga mengandungi ilmu pendidikan dan psikologi yang tinggi nilainya di mata para pendidik bangsa. Bagi mencapai objektif ini, pengkaji 
melihat hubungan erat yang signifikan antara ketiga-tiga karya Tuan Hasan Besut dalam membentuk suatu gagasan teori pendidikan dan psikologi milik beliau sendiri. Hal ini menjelaskan persoalan kenapa beliau begitu dihormati sebagai seorang pendidik ulung, "guru pertama" masyarakat Besut di zamannya.

\section{Rujukan}

Ahmad Fathy al-Fatani. Ulama Besar dari Patani. Bangi: Penerbit Universiti Kebangsaan Malaysia, 2002.

Al-Dhahabī, Shams al-Dīn Muḥammad ibn Aḥmad. Siyār A 'lām al-Nubalā', ed. Bashshar 'Awwad Ma'ruf dan Muhy al-Dīn Hilal al-Sarhan. Cet. 11, Beirut: Mu' assasah al-Risālah, 1996.

Al-Zirikli, Khayr al-Dīn. Al-A'lam. Beirut: Dār al-'Ilm li alMalāyīn, 2002.

Amer Hudhaifah Hamzah. "Qaḍāyā al-Makhțuṭāt alMalāyūwiyyah: Ațrūḥah Fikriyyah wa Iqtirāḥ." Prosiding Seminar Antarabangsa Penyelidikan Alam Melayu, 2017. Amer Hudhaifah Hamzah. "Kitab al-Risalah al-Fataniyyah fi alNahw: Tahqiq dan Analisis Kandungan." Disertasi, Fakulti Pengajian Islam, Universiti Kebangsaan Malaysia, 2016.

Anon, "PNM Boleh Jadi Tarikan Pelancong", laman sesawang Sinar Online, https://goo.gl/LA9XCk, dicapai pada 14 Oktober 2017.

Bergstraesser, Gotthelf. Ușūl Naqd al-Nușūṣ wa al-Nashr, ed. Muhammad Hamdi al-Bakri. Riyaḍ: Dār al-Mirrikh, 1982.

Dzul Haimi Md. Zain dan Md. Yusoff Othman. Ragam Hias alQur'an di Alam Melayu. Kuala Lumpur: Utusan Publications \& Distributors Sdn. Bhd., 2007.

Hārūn, 'Abd al-Salām. Taḥqīq al-Nușūṣ wa Nasharuhā. Cet. ke 7, Kaherah: Maktabat al-Khanji, 1998.

Hassan Omar. "Caj Tinggi Punca Manuskrip Melayu Tersimpan di Britain," laman sesawang Berita Harian, dicapai pada 14 Oktober 2017, https://goo.gl/smq7nx.

Ibn Aybak, Șalāḥ al-Dīn Khalil. Al-Wāfì bi al-Wafāyāt, ed. Aḥmad al-Arna'ut dan Turki Mușțafā. Beirut: Dār Ihyā̄ al-Turath al'Arabī, 2000.

Ibrahim Syukri. Sejarah Kerajaan Melayu Patani. Bangi: Penerbit Universiti Kebangsaan Malaysia, 2005. 
Mohd Ekhbar Daud dan Farid Mat Zain. "Peranan Ulama dalam Perkembangan Islam di Besut, Terengganu: Satu Pemerhatian Awal", Jurnal AL-ANWAR 1, no.3 (2017), 105.

Mohd Ekhbar Daud dan Farid Mat Zain. "Perkembangan Awal Islam di Besut, Terengganu." Prosiding Kolokium Antarabangsa Siswazah Pengajian Islam (KASPI), 2015.

Mohd Fauzi Hamat dan Mohd Hasrul Shuhari. "Pengaruh Pemikiran Akidah al-Ghazali dalam Kitab Jawi: Tinjauan Terhadap Kitab al-Durr al-Nafis dan Siyar al-Salikin", Jurnal Usuluddin 36 (2012), 32.

Muhammad Abu Bakar. Ulama Terengganu Suatu Sorotan. Kuala Lumpur: Utusan Publication \& Distributors Sdn. Bhd., 1991.

Șalāḥ al-Dīn al-Munajjid, Qawā id Tahquīq al-Makhțūtāt. Cet. ke 7, Kaherah: Dār al-Kitab al-Jadīd, 1987.

Siti Hawa Haji Salleh. "Ruang Lingkup Pengajian Filologi Melayu", Jurnal Filologi Melayu 3 (1994), 4.

Wan Ali Wan Mamat. "Persiapan untuk Kerja Menulis Manuskrip" dlm. Warisan Manuskrip Melayu. Kuala Lumpur: Perpustakaan Negara Malaysia, 2002.

Wan Hasan al-Fatani, Hidāyat al-Mukhtār fi Faḍl Talab al-'Ilm wa Faụl Șāhabihi min Kalām Sayyīd al-Akhyār. T.tp: t.pt, t.t.

Wan Mohd Shaghir. Penyebaran Islam \& Silsilah Ulama Sejagat Dunia Melayu. Kuala Lumpur: Persatuan Pengkaji Khazanah Klasik Nusantara \& Khazanah Fathaniyah, 2000. 